\title{
Generating Renewable Electricity from Food Waste
}

\author{
M.A.O. Mydin ${ }^{1}$, N.F. Nik Abllah ${ }^{2}$, N. Md Sani ${ }^{3}$, N. Ghazali ${ }^{4}$, N.F. Zahari ${ }^{5}$ \\ ${ }^{1,2,3,4}$ School of Housing, Building and Planning, Universiti Sains Malaysia, 11800 Penang, Malaysia \\ ${ }^{5}$ Faculty of Architecture, Planning and Surveying, UiTM Perak, Seri Iskandar Campus, 32610, Seri \\ Iskandar, Perak, Malaysia
}

\begin{abstract}
Mini biogas power plant (MBPP) was first used and launched in Malaysia by Universiti Sains Malaysia (USM). USM with the collaboration with Enerbon Sdn Bhd had set up this mini biogas power plant as an education and research and development tools to professionals and researchers and at the same time giving opportunities to people who are interested with this system to witness and experience it themselves by looking at how this mini biogas power plant works. There are 2 main objectives of this study being carried out; firstly to determine whether food wastes (canteen and cafeterias wastes) can produce methane gas (biogas) that can generate heat and electricity and secondly to establish how much methane gas (biogas) can be produced with the certain amount of the feedstock. It should be pointed out that this MBPP can generate $600 \mathrm{~kW}$ electricity per day as this system can generate electricity about $25 \mathrm{~kW} / \mathrm{h}$. The methane produced per day is approximately 180 cubic metres. The higher the wastes, the higher the amount of methane gas produced. The cow dung is used to increase the bacteria in the tank; the methane gas production will be higher if the bacteria breed.
\end{abstract}

\section{Introduction}

Biogas typically refers to a gas produced by the breakdown of organic matter in the absence of oxygen. It is a renewable energy source, like solar and wind energy. Furthermore, biogas can be produced from regionally available raw materials and recycled waste and is environmentally friendly and $\mathrm{CO} 2$ neutral. Biogas is produced by the anaerobic digestion or fermentation of biodegradable materials such as manure, sewage, municipal waste, green waste, plant material, and crops [1]. Biogas comprises primarily methane $(\mathrm{CH} 4)$ and carbon dioxide $(\mathrm{CO} 2)$ and may have small amounts of hydrogen sulphide (H2S), moisture and siloxanes. The gases methane, hydrogen, and carbon monoxide (CO) can be combusted or oxidized with oxygen [2].

This energy release allows biogas to be used as fuel. Biogas can be used as fuel in any country for heating purposes, such as cooking and more. It can also be used in anaerobic digesters where it is typically used in a gas engine to convert the energy in the gas into electricity and heat [3]. Biogas can be compressed, much like natural gas, and used to power motor vehicles. In UK for instance, biogas is estimated to have the potential to replace about $17 \%$ of vehicle fuel. Biogas is a renewable fuel so it qualifies for renewable energy subsidies in some parts of the world [4]. Biogas can also be cleaned and upgraded to natural gas standards when it becomes bio methane. 
Mini biogas power plant (MBPP) which was first launched in Malaysia at Universiti Sains Malaysia (USM) is capable of generating $600 \mathrm{~kW}$ of electricity daily from food waste in the campus. This pioneering project is aimed of building a prototype to be used by internal communities with problems pertaining obtaining regular electricity supply [5]. Food waste supplied by all cafeterias and canteens in the campus will be converted into methane which will be generating electricity [6,7]. The plant has two tanks that can accommodate $1000 \mathrm{~kg}$ of food and organic waste such as grass, vegetables waste, leftover rice and leftover fish. The electricity generated could be channelled to the university's power supply grid $[8,9]$. Communities with a lot of organic waste but no connection to the grid would benefit most from MBPP, in which MBPP per se produces approximately 180 cubic metres of methane a day from readily available local waste material $[10,11]$.

This paper will focus about feasibility study on mini biogas power plant (MBPP) which is first developed and operated in Malaysia and launched at Universiti Sains Malaysia (USM). USM with the collaboration Enerbon Sdn Bhd setup up this mini biogas power plant as an education and research and development to professionals and researchers and at the same time give opportunity to the people who are interest with this system to see and experience their self by looking how this mini biogas power plant works. The objectives of this paper are two-fold; firstly to determine whether food wastes (canteen and cafeterias wastes) can produce methane gas (biogas) that can generate heat and electricity and secondly to establish how much methane gas (biogas) can be produced with the certain amount of the feedstock

\section{Setup of Mini Biogas}

As mentioned in the previous section, the aim of this study is to distinguish whether this mini biogas power plant could generate methane gas and produce electricity as much as being produced by other countries by means of food wastes as the feedstock. Fig. 1 shows the modular concept of the mini biogas power plant which is in prefabricated design and can be installed easily.

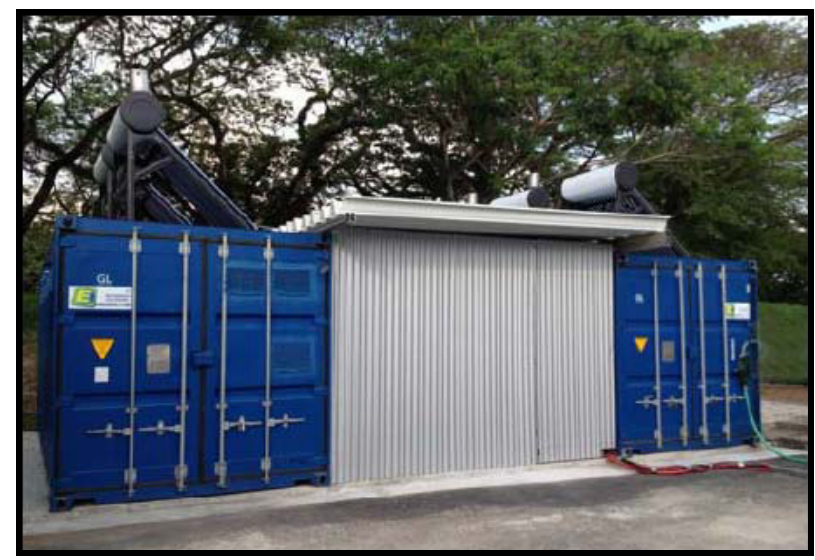

Figure 1: Prefabricated mini biogas power plant

This mini biogas power plant will indicate the amount of methane gas produced with the certain amount of feedstock used everyday. This machine works 24 hours per day with total amount of feedstock ranging from $200 \mathrm{~kg}$ to $1000 \mathrm{~kg}$. These mini biogas power plants use anaerobic digestion (no present of oxygen) and the feedstock is mixed with the cow dung and water. The feedstock came from canteens and cafeterias waste for example leftover rice, vegetables waste, fish waste, fruits and any other food leftovers. Fig. 2 demonstrates the room where the temperature and $\mathrm{pH}$ value were controlled. 


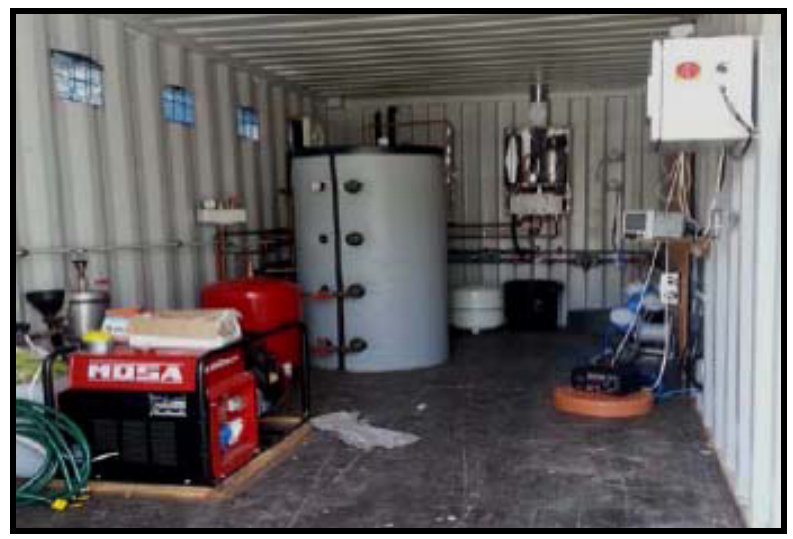

Figure 2: Temperature and $\mathrm{pH}$ value were set and controlled in special room

By using food waste and organic waste from cafeterias and canteens around the campus, this mini biogas power plant will digest all the waste and turn it into methane in order to produce electricity. With the total amount of $1000 \mathrm{~kg}$ of mixed food waste per day, there is about 180 cubic metre of methane can be produced and about $600 \mathrm{~kW}$ electricity can be generated. The digesters that are used for the purpose of production of biogas can be used in mesophilic conditions, which mean a temperature range of 20 to 25 degrees Celsius to 40 to 45 degrees Celsius. The digesters can also be run in thermophilic conditions, where the temperature range is from 50 to 55 degrees Celsius to 60 to 65 degrees Celsius. Both these conditions call for separate species of bacteria. It is notedthat the mesophilic operations are safer and more stable than the thermophilic operations that are capable of inactivating the parasites of animals and the various pathogens. Through the lab test that has been conducted in the environmental lab, the temperature of the water in the tank 1 and in the digester are $35.7^{\circ} \mathrm{C}$ and $37.5^{\circ} \mathrm{C}$ respectively. Fig. 3 shows samples that were taken from tank and digester.

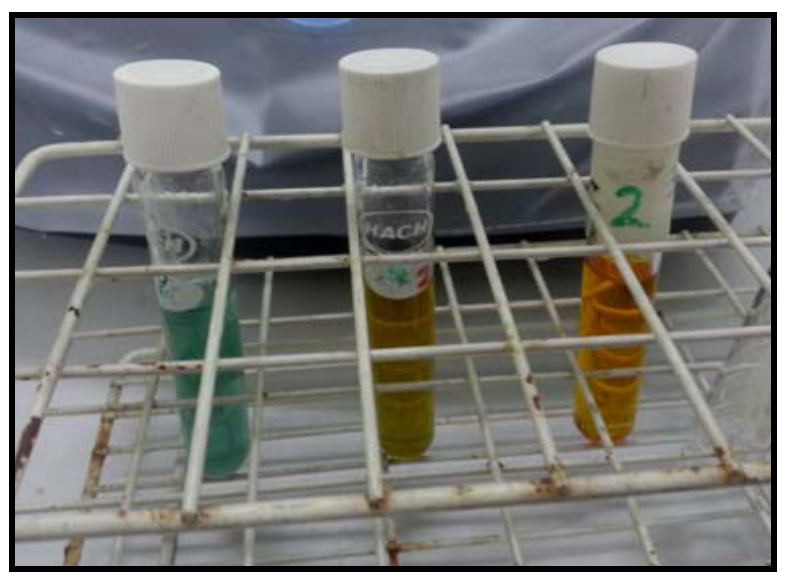

Figure 3: Samples taken from tank and digester

At the hydrolysis process it is important to make sure that the $\mathrm{pH}$ value are 4 to 5 and for the methanogenesis are 7 to 8 . Preparation of feeding substrate for $\mathrm{pH}$ value is very important with the condition no oxygen and darkness is about less than $1 \%$. The heating of digesters is also pretty important in this regard. The $\mathrm{pH}$ of the slurry has to be close to 7 . This is pretty much possible provided that cow dung is employed in the form of a substrate. If favourable conditions may be provided then as much as sixty litres of biogas may be produced for one kilogram of cow dung. Through the lab test that has been conducted in the environmental lab, the $\mathrm{pH}$ values obtained from tank 1 and in the digester are 4.78 and 7.11 correspondingly. 


\section{Results from Hypothetical Case Study}

The results obtained from the hypothetical case study, the result is shown in Table 1. The mini biogas system costs about RM1.0 - RM 1.2 millions including the operational cost which is diesel that costs RM4 per litre. This mini biogas power plant needs only a battery backup of about 6 hours to add fuels on the generator or when doing maintenance to the generator. The cost for solar energy system is higher than biogas system which sums up around RM 4.5 Million due to the cost for battery backup. Solar energy system needs battery backup when it is raining or cloudy, that makes the solar panel unable to receive sunlight. In this situation, solar panel cannot generate any electricity. The cost for battery backup makes the solar system's cost higher than biogas.

This system can be installed easily due to it being modular which means it is portable and can be transferred and installed anywhere. The biogas mini power plant only needs food and organic waste to generate electricity energy and the generator is guaranteed to work 24 hours a day regardless of the weather. The supply of wastes is continuous as long as there are people that lives in the vicinity; ensuring that this system will work well. If solar system is used, it may cause a problem during rainy day because the system will not be able to receive any sunlight and needs battery for backup.

Table 1: The comparison between biogas' and solar system's costs

\begin{tabular}{|c|l|l|}
\hline $\begin{array}{c}\text { Types of } \\
\text { energy }\end{array}$ & \multicolumn{1}{|c|}{ Biogas with generator } & \multicolumn{1}{c|}{ Solar energy with batteries } \\
\hline Source & $\begin{array}{l}\text { Needs } 1000 \mathrm{~kg} / \text { day organic feedstock and } \\
\text { operator }\end{array}$ & $\begin{array}{l}\text { Needs } 150 \mathrm{kWp} \text { panel capacity with 4-5h } \\
\text { max sun shine plus additional light }\end{array}$ \\
\hline Efficiency & $600 \mathrm{~kW}$ and $182 \mathrm{~m}^{3}$ Methane Gas per day & $\begin{array}{l}\text { 4hours sunshine (150kWp x 4) }=600 \mathrm{~kW} \\
\text { per day }\end{array}$ \\
\hline Operational cost & $\begin{array}{l}\text { Need diesel to run the generator (1 litres } \\
\text { diesel = RM4 ) }\end{array}$ & No need \\
\hline Battery backup & Battery backup for 6 hour only & $\begin{array}{l}\text { Battery backup for 2 days (for raining and } \\
\text { cloudy day) }\end{array}$ \\
\hline Production & Gas and electricity & Electricity \\
\hline Cost & RM $1.0-1.2$ Million & $\begin{array}{l}\text { RM4.5 Million (needed a lot of battery } \\
\text { backup for raining days) }\end{array}$ \\
\hline
\end{tabular}

By having an amount of $1000 \mathrm{~kg}$ waste per day, the electricity generated will be about $600 \mathrm{~kW}$ per day due to the fact that this mini biogas power plant can produce up to $25 \mathrm{kWh}$. About 180 cubic metre methane gas is produced and will be burned to generate electricity. If there are more wastes, the electricity energy generated will also increase. The maximum electricity that can be generated by this mini biogas power plant is $720 \mathrm{Kw}$ with the amount of waste of $1200 \mathrm{~kg}$ per day. The result of the methane and electricity produced is as shown in Table 2 below.

Table 2: The production of methane gas and electricity per day

\begin{tabular}{|c|c|c|c|c|}
\hline \multicolumn{5}{|c|}{ Feedstock - Organic active (canteens and cafeterias waste) } \\
\hline \multirow[t]{3}{*}{ Feedstock substrate } & \multirow{2}{*}{\multicolumn{2}{|c|}{$\begin{array}{c}\text { CH4/VS and /Feedstock } \\
\left(\mathrm{m}^{3} \mathrm{CH} 4 / \mathrm{kg} \mathrm{VS}\right)\end{array}$}} & \multicolumn{2}{|c|}{ Power/tFs (per day) } \\
\hline & & & $\mathrm{kWh} / \mathrm{d}$ & $\mathrm{kWh} / \mathrm{h}$ \\
\hline & 0.196 & 196.0 & 646.80 & 26.95 \\
\hline
\end{tabular}

The production of biogas result indicated that about $26.95 \mathrm{kWh} / \mathrm{h}$ electricity can be generated with the total amount of $1000 \mathrm{~kg} / \mathrm{d}$ of food waste supplied. There is about $646.80 \mathrm{kWh} / \mathrm{d}$ electricity can be produced a day. Methane gas that can be produced per day is 196.0 cubic metres. It is proved that all the foods waste from canteens and cafeterias can generate more methane gas and electricity. The dry matter content in this mixed waste is about $40 \%$ while the volatile solid makes up about $98 \%$. The result shown was higher from other country's results because this mini biogas power plant has a change in their design that increases their workability and efficiency. 
Table 3 shows the amount of the feedstock used by week. The amount of feedstock is same in week 1 to week 3 because the bacteria in the tank (cow dung) need at least 3 weeks to multiply the bacteria. The higher the bacteria, the higher the methane gas production. At the week 4 until week 12 the amount of feedstock place in the tank increase to multiply the bacteria but until $1000 \mathrm{~kg}$ the feedstock will remains constant.

Table 3: Table of feedstock used per week

\begin{tabular}{|c|c|c|}
\hline Weeks & Amount of feedstock $(\mathrm{kg})$ & Amount of methane gas production $\left(\mathrm{m}^{3}\right)$ \\
\hline 1 & 200 & 35.48 \\
\hline 2 & 200 & 37.23 \\
\hline 3 & 200 & 39.20 \\
\hline 4 & 400 & 70.76 \\
\hline 5 & 400 & 78.40 \\
\hline 6 & 500 & 98.00 \\
\hline 7 & 600 & 117.60 \\
\hline 8 & 700 & 137.20 \\
\hline 9 & 800 & 156.80 \\
\hline 10 & 900 & 176.40 \\
\hline 11 & 1000 & 196.00 \\
\hline 12 & 1000 & 196.00 \\
\hline
\end{tabular}

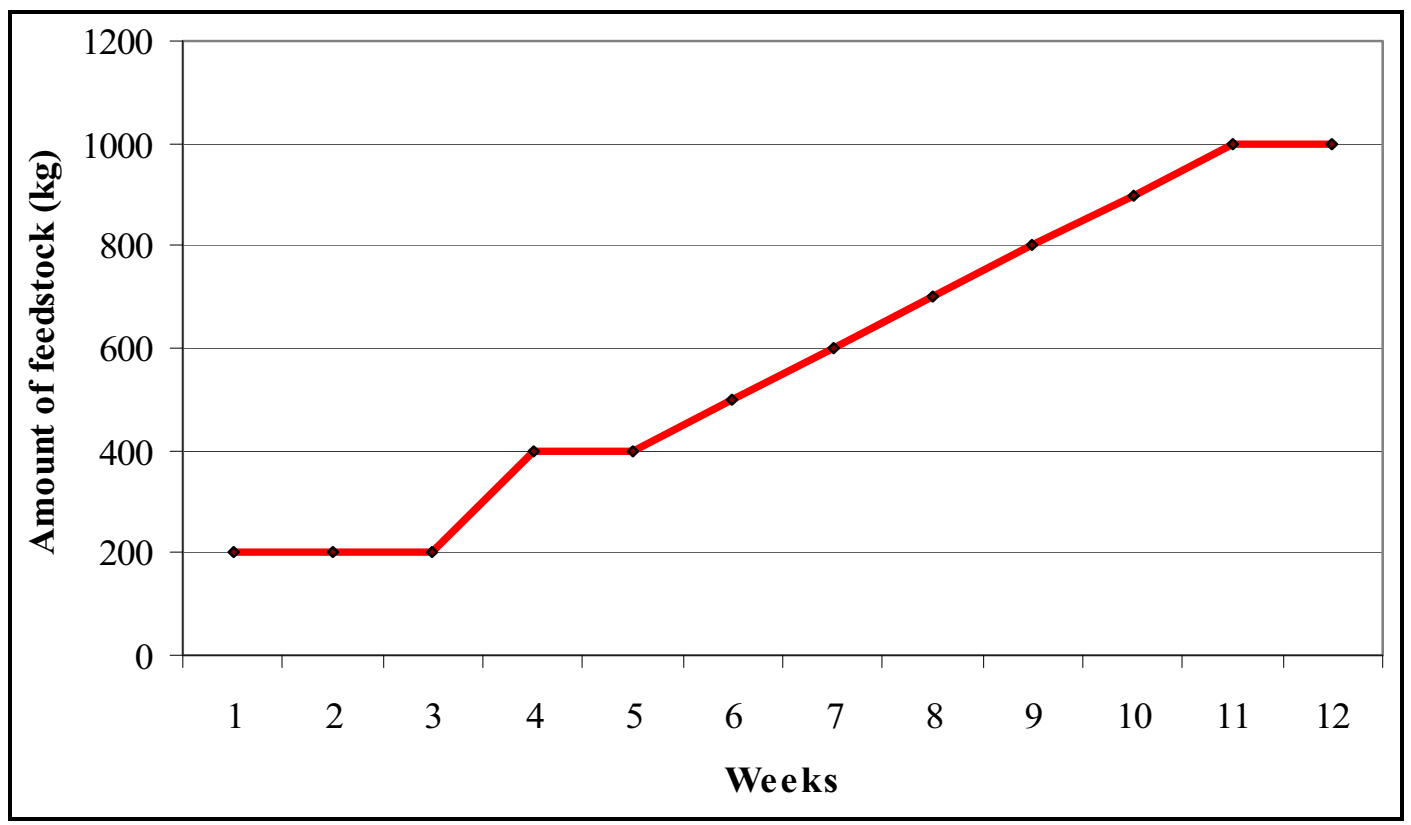

Figure 4: The amount of feedstock used by week

Based on Fig. 4, it is shows the increasing of the number of the feedstock by the weeks. This MBPP already function about 3 months, and at the week 11 to week 12 the number of feedstock's are remain constant. On the other hand, according to Fig. 5 shows the amount of methane gas produced per week where the production of methane gas production increases when the feedstock increases. At the beginning, the number of feedstock is $200 \mathrm{~kg}$ and the number of methane gas produced is around $35.48,37.32$ and 39.20 respectively. 


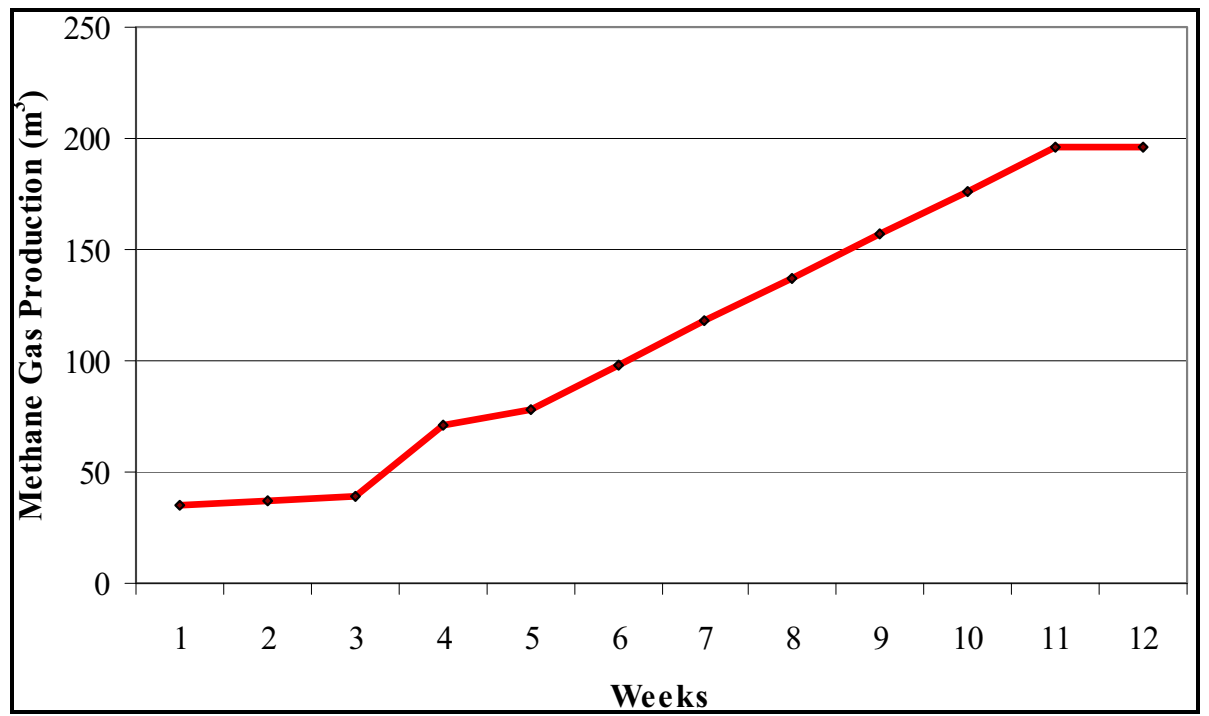

Figure 5: The amount of methane gas produced per week

Fig. 6 shows the number of electric generated increase by weeks is remains constant at the week 11 and 12 with the amount of $646.80 \mathrm{~kW}$. It clearly visualised that the amount of electric power increase by weeks.

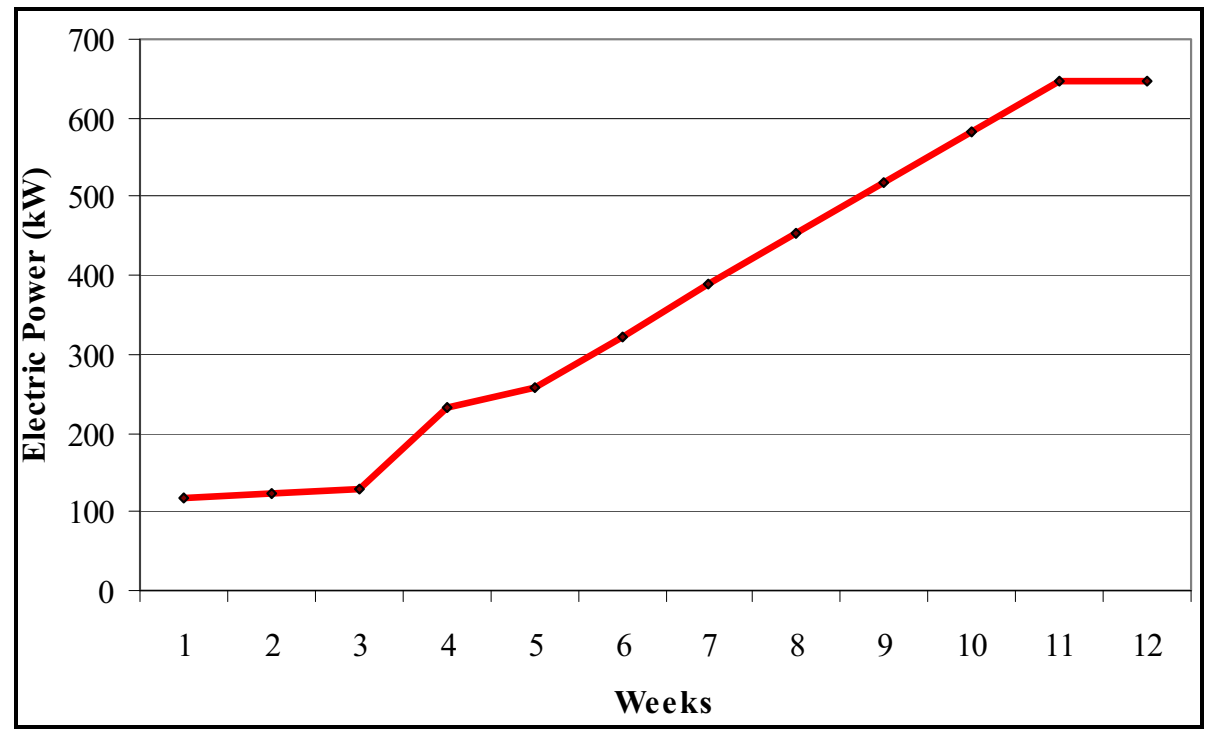

Figure 6: The number of electric power generated per week

\section{Conclusions}

The most suitable power plant system to be installed at remote area is mini biogas power plant compared to solar energy system because of several reasons. First of all, this mini biogas power plant is easy to set-up because it is made in a modular system that could be installed or uninstalled and transferred easily everywhere and anywhere. When there is a human, there will be waste. It is not hard to collect the wastes to be used in generating the energy rather than waiting for the sunlight that is dependable on the weather. If it is raining season, they villagers will not suffer to stay in dark at night 
and feeling hot during the day. The generator will work 24 hours to generate electricity as long as there are wastes and the generator have enough fuels to work.

If there is $1000 \mathrm{~kg}$ waste per day, the mini biogas power plant can generate about 180 cubic metre methane gas and $600 \mathrm{~kW}$ electricity per day. The waste produced should be enough to support this system. It is acceptable if the waste is lower than $1000 \mathrm{~kg}$ per day, as long as it could support all the needs that the people demand at their place. The higher the amount of wastes could produce the higher the amount of electricity.

\section{References}

1. Corral, M., M. Argelia, 2007. Biogas production via anaerobic digestion of high solids livestock manures, PhD thesis, New Mexico State University, 593-599

2. Babel, S., J. Sae-Tang, A. Pecharaply, 2009. Anaerobic co-digestion of sewage and brewery sludge for biogas production and land application. International Journal of Environmental Science and Technology, 6 (1): 131-140.

3. Ilaboya, I.R., F.F. Asekhame, M.O. Ezugwu, A.A. Erameh, F.E. Omofuma, 2010. Studies on Biogas Generation from Agricultural Waste; Analysis of the Effects of Alkaline on Gas Generation. World Applied Sciences Journal 9 (5): 537-545

4. Wiley, P.E., J. Campbell, B. McKuin, 2011. Water Environment Research, Production of Biodiesel and Biogas from Algae: A Review of Process Train Options. Water Environment Research, 83 (4): 326-338

5. Ofori-Boateng, C., E.M. Kwofie, 2009. Water Scrubbing: A Better Option for Biogas Purification for Effective Storage. World Applied Sciences Journal 5 (Special Issue for Environment), 122125

6. Ilyas, S.Z., 2006. A Case Study to Bottle the Biogas in Cylinders as Source of Power for Rural Industries Development in Pakistan. World Applied Sciences Journal, 1 (2): 127-130

7. Rapport, J.L., 2011. Large scale anaerobic digestion of food processing waste and pre-treatment of agricultural residue for enhancement of biogas production, 12: 23-29

8. Waqar Bhatti, M., 2012. Mini biogas plant reducing dependence on the firewood, International The News, Karachi, 54: 42-53

9. Ahn, H.K., M.C. Smith, S.L. Kondrad, J.W. White, 2012. Evaluation of Biogas Production Potential by Dry Anaerobic Digestion of Switch grass-Animal Manure Mixtures, Applied Biochemistry and Biotechnology, 160 (4): 965-975

10. 10. Najafi, Z. N. Jaafarzadeh, 2007. Biogas Production From Animal Manure And Vegetable Wastes, The Social Contex, 48 (2): 52-54

11. Manikam, N.S.T., 2012. Report of Biogas Production From The Municipal Waste, B.Sc final year project, Faculty of Engineering and Science, Universiti Tunku Abdul Rahman, 432-437 